DOI: 10.15290/rtk.2018.17.2.09

iD $0000-0001-8359-9060$

iD $0000-0002-2244-7546$

Antonio Uricchio

Università degli Studi di Bari Aldo Moro

Joanna Radwanowicz-Wanczewska ${ }^{1}$

Uniwersytet w Biatymstoku

\title{
Respecting an Individual's Subsistence Minimum in Administrative Enforcement Proceedings
}

Multidimensional changes are taking place in the modern world. Generally speaking, these changes concern what is broadly understood as culture, civilization, and religion. These changes can be perceived through their connection with technology, which affects how societies are organized, how people exercise power (politics), the types and features of social bonds, what the economy looks like, man and his existential situation, and man's relationship with himself and his surroundings. These changes also definitively impact administrative enforcement proceedings, which can use coercion to make the obligor fulfill his obligations. Because coercive measures may be used on the obligor during the course of administrative enforcement proceedings, they should be carried out with due care for the good of the individual. This study analyzes principles for respecting the obligor's mandatory subsistence minimum as well as his role in counteracting excessive interference on the part of public administrational bodies in his individual rights and freedoms.

Key words: coercion, administrative enforcement proceedings, subsistence minimum.

An article is a result of research work of co-author conducted in part during her stay as a visiting professor at the Università degli Studi di Bari Aldo Moro. 
People have always sought ways to meet their needs, and making changes affects the ways in which they achieve this. Over the centuries, one can see how changes in customs affect human behavior and the phenomena that are inextricably linked with it. One such phenomenon is coercion. People are subject to the processes that take place as societies become civilized. If one considers this in historical, sociological, and psychological categories, then it is clear that these processes unfold independently of our will and brings about certain effects. The individual who functions in a given society has specific rights and must equally fulfill certain public legal obligations. In the event that an individual does not voluntarily meet these obligations, then those in authority have the right to apply measures that will ensure that he behaves in a desirable manner. In some cases, authorities are even authorized to enforce these behaviors through the use of physical force. Legally, only those invested with authority to exercise state or national power can use physical force. As civilizations have developed, the use of coercion and physical force (which has taken on many and often extremely cruel forms ${ }^{2}$ in the past) is being replaced with other more civilized methods that are able to ensure that an individual will fulfill his duties.

This study considers the issue of administrative enforcement proceedings, the essence of which ${ }^{3}$ are carried out by "public administrative bodies appointed by law who take all of the necessary steps foreseen by the law to bring the factual state of affairs into conformity with individual or general legal norms. This entails that the titularly designated recipient has duties that are subject to compulsory administrative, and not judicial, enforcement." ${ }^{4}$ As a rule, this concerns

2 For more on the topic of using administrative coercion in ancient times, see J. Radwanowicz-Wanczewska, Poczatki przymusu administracyjnego w prawie rzymskim i praktyce rzymskiej administracji, "Administracja. Teoria - Dydaktyka - Praktyka” 2015, no. 4 (41), pgs. 80-121.

As D. R. Kijowski notes, "administrative enforcement proceedings should be understood in two ways. Strictly speaking, they should be understood as the procedural steps taken by the administrative enforcement authority, its employees, those designated to take action on the authority's behalf, and (eventually) the requisition authority in order to enforce the obligation imposed on the obligor. In the broad sense, they should be understood as the activities of other bodies and persons (creditors and those who provide assistance and help in the activities pertaining to execution)." D. R. Kijowski, in Ustawa o postepowaniu egzekucyjnym $w$ administracji. Komentarz, ed. D. R. Kijowski, $2^{\text {nd }}$ Edition, Warsaw 2015, pg. 34 .

4 D. R. Kijowski, in Ustawa...,pg. 34. See also E. Smoktunowicz, in Wielka encyklopedia prawa, ed. E. Smoktunowicz [et al.], Warsaw - Białystok 2000, pg. 207. 
individuals' civil and legal obligations (i.e. those that result from the legal and administrative relations) that are within the scope of the substantive jurisdiction of governing administrative bodies and local self-governing bodies. The regulations concerning administrative enforcement proceedings ${ }^{5}$ that are binding in Poland as of July 17, 1966 specify the means that enforcing bodies can use to coerce an individual to carry out his financial or nonmonetary obligations. On the other hand, the provisions of the aforementioned act also aim to ensure that the individual's rights are protected against the use of coercion. The precepts of the law play an important role in ensuring this protection. The entire legal system has general precepts for administrative enforcement proceedings, which are defined in the Code of Administrative Proceedings, ${ }^{6}$ as well as general precepts for the administrative enforcement proceedings contained in the Law for Administrative Enforcement Proceedings [in Polish: ustawy o postępowaniu egzekucyjnym w administracji (u.p.e.a.); hereafter abbreviated in English as l.a.e.p.].

As of April 2, 1997, the Constitution of the Republic of Poland ${ }^{7}$ upholds that the entire Polish legal system guarantees, among other things, the protection of the individual from coercion. The literature also indicates the precept of a democratic state that is ruled by law as an example of the application of administrative enforcement proceedings. According to Article 2 of the Constitution of the Republic of Poland, Poland is a democratic state that is ruled by law and, therefore, has the obligation to reflect a universally recognized value system, including and above all human dignity and freedom. Any departure from contemporary standards in this area is contrary to the idea of a legal state. ${ }^{8}$ This article does not aim to present the general precepts of an entire system of law, the general principles of administrative proceedings regulated by the Code of Administrative Proceedings [Kodeks Postępowania Administracyjnego; hereafter abbreviated in English as c.a.p.], or the principles that are characteristic of administrative enforcement proceedings regulated in the l.e.p.a., since this

Dz. U. z 2017 r. poz. 1201 ze zm. Abbreviated hereafter as l.a.e.p.

Act of June 14, 1960, Code of Administrative Proceedings, Dz. U. z 2017 r. poz. 1257 ze zm. Hereafter abbreviated as c.a.p.

Dz.U. Nr 78, poz. 483 ze zm.

For more on this topic, see: J. Radwanowicz-Wanczewska, Administracyjne postępowanie egzekucyjne a aksjologia demokratycznego państwa prawnego, in Aksjologia prawa administracyjnego, ed. J. Zimmermann, T. 1, Wolters Kluwer, Warsaw 2017, pgs. 1099-1113. 
would be beyond its scope. Instead, this article considers the impact of general administrative enforcement proceedings on an individual's situation, specifically with regard to the issue of respecting the subsistence minimum, which the literature has indicated (and is otherwise known) as the principle of respect for the obligor ${ }^{9}$ contained in Articles 8-13 of the l.a.e.p. Moreover, the reflections below pertain only to the protection of the rights of a physical person who is the obligor (and not, for example, a witness or assessor) in administrative enforcement proceedings.

The general administrative principles of enforcement proceedings contain basic guidelines that should be followed during such proceedings. At the same time, these principles indicate features that are specific to enforcement proceedings and their main assumptions. These principles also serve to protect the rights of the obligor. ${ }^{10}$ The very important role that the general principles of administrative enforcement proceedings play in the protection of the obligor's rights means that, if they are violated (like other legal norms) in the proceedings, then the bodies conducting these proceedings must take certain actions to exercise supervision and control. ${ }^{11}$ The principle of respecting the subsistence minimum, to which this study is devoted, is expressed in administrative execution of the obligor's assets only in the areas that do not threaten the minimum necessary to maintain the obligor

9 The list of assets that are exempt from execution under the provisions of Article $8 \S 1$ and 2, point 5 as well as the regulations resulting from Article $8 \mathrm{a}-10$ and 12-13 of the l.a.e.p. are the basis for asserting that these exemptions make up the general rule of enforcement proceedings referred to as the principle of respect for the obligor's human dignity. See P. Przybysz, Postępowanie egzekucyjne $w$ administracji. Komentarz, Warsaw 2008, pg. 66. M. Ofiarska also points out this principle. See M. Ofiarska, Znaczenie zasad ogólnych administracyjnego postępowania egzekucyjnego worzecznictwie sądówadministracyjnych, Annales Universitatis Mariae Curie-Skłodowska Lublin - Polonia, Sectio H Oeconomia 2016, no. 1, pg. 240. See also the decree that the Provincial Administrative Court in Gorzow Wielkopolski issued on October 20, 2008, I SA/Go 678/08, LEX nr 576720. Due to the scope and subject matter provided for in the exclusions contained in the l.a.e.p., the literature also indicates that Articles 8-10 of the l.a.e.p. influence the general principle of broad exclusions from execution. See J. Służewski, in Postępowanie administracyjne, ed. J. Służewski, Warsaw 1975, pg. 166.

10 Por.Z.Leoński, in R.Hauser,Z.Leoński,Egzekucja administracyjna. Komentarz do ustawy o postępowaniu egzekucyjnym $w$ administracji, 3rd Edition, Warsaw 1995, pg. 21.

11 Por. R. Hauser, Ochrona obywatela $w$ postępowaniu egzekucyjnym $w$ administracji, Poznan 1988, pg. 52 as well as the literature provided therein. 
and those who are supported by him while the obligor fulfills his legal obligations.

The restrictions on enforcement that ensure the subsistence minimum are twofold. On the one hand, the Act lists specific objects, claims, and property rights that, by law, are not subject to enforcement. On the other hand, it also exempts the enforcement authority from executing specific assets pursuant to Article 13 of the la.e.p. The principle of respecting the subsistence minimum applies mainly to enforcing cash benefits. According to this principle, administrative enforcement proceedings should not deprive the obligor and his dependents of the minimum subsistence level-that is to say, the means of subsistence and the possibility to be gainfully employed. According to the l.a.e.p., determining the objects that are necessary for an individual is not, however, sufficiently precise. Exemptions from exclusion that are specified in the Act are applicable primarily to real people. The literature points out that the exclusion of certain goods from execution also has a different meaning-namely, it pertains, among other things, to the formulation of certain preferences for the bodies who implement the state's financial policy. For example, by excluding a part of an individual's savings that he deposited at a bank, credit union, or in a cooperative savings, economic incentives were created to invest money in this way. ${ }^{12}$

According to Article $8 \S 1$, points $6,10,11$, and 14 of the l.a.e.p., the legislator unambiguously specifies the obligor's assets that are not subject to enforcement. In the remaining cases, the legislator's calculation may necessitate, for example, explanations or interpretations. ${ }^{13}$ The enforcement exemption included in the Act specifies three kinds of property: items, sums of money, active debts, and property rights. According to Article $8 \S 1$ of the l.a.e.p., items include household appliances, bedding, underwear, and clothing that are necessary for the obligor and his dependents as well as clothing that is necessary to perform a job, service, or profession. As a result of the above, a specific item is excluded if it is considered "indispensible," which in itself is complicated. Because the Act is vague, it is necessary to judicially determine what is "indispensible" to the obligor. The literature points out that it is necessary to consider this issue in light of how it complies with the action indicated in Article $8 \S 1$, point 1 of the l.a.e.p. and with the constitutional principle of respecting a person's dignity, ${ }^{14}$ since

2 See M. Ofiarska, Znaczenie zasad..., pg. 240.

13 See D. R. Kijowski, in Ustawa o postępowaniu..., pg. 243.

$14 \quad$ Ibid, pg. 245. 
some judgments might raise doubts. For example, a decision made by Poland's Supreme Administrative Court states that "The wall unit and refrigerator are items subject to administrative execution. These are not basic home appliances that are necessary for the debtor and his family." ${ }^{15}$ Representatives of this doctrine rightly question the legitimacy of including such items in administrative execution and point to the danger of violating the provision contained in Article 8 § 1, points 1 and 9 of the l.a.e.p. ${ }^{16}$

In order to specify the scope of enforcement exemptions, Article $8 \S$ 2 of the l.a.e.p. states that some items are not considered necessary to the obligor and the members of his family. These items include: stylish and stylized furniture, color televisions (unless the obligor shows that more than 5 years have passed since the year that the TV was produced), computers and accessories (unless they are necessary for the obligor to work), high-quality fur, porcelain, decorative glass and crystal, cutlery made from precious metals, and works of art. This list, however, is neither exhaustive (as indicated by the use of the phrase "in particular") nor completely precise. Doubts regarding how to understand, for example, terms such as decorative glass, works of art, etc. might arise.$^{17}$ In turn, Article 8a of the l.a.e.p. provides a comprehensive list of tools, equipment, farm animals, and other things that are not subject to execution because they are necessary to run a farm. The literature indicates a wide range of execution exemptions of things that are highly valuable that belong to farmers. Some authors point out that the privileges granted to this group of citizens is incompatible with the constitutional principle of citizens' equality before the law. ${ }^{18}$

The exclusions provided in the Act also make it necessary for the obligor to engage in gainful employment, study, service, and a profession. This includes the execution exemption of tools and other objects that are necessary for the obligor to personally perform his job, excluding, however, the means of transportation and raw materials necessary for this work for a period of 7 days as well as items that are necessary for the obligor and his family members to learn, and for the obligor to perform service or carry out his work.

15 Judgment of the Supreme Administrative Court in Lodz issued on December 18, 1996, SA/Łd 2983/95, LEX nr 28977.

See D. R. Kijowski, in Ustawa o postępowaniu..., pg. 245.

See M. Masternak, in T. Jędrzejewski, M. Masternak, P. Rączka, Administracyjne postępowanie egzekucyjne, Torun 2013, pg. 57.

W. Piątek, A. Skoczylas, in Postępowanie egzekucyjne w administracji. Komentarz, ed. R. Hauser, A. Skoczylas, Warsaw 2014, pg. 84. 
Doubts may arise regarding exluding means of transportation. ${ }^{19}$ According to the provision of Article $8 \S 1$, point 4 of the l.a.e.p., and reflected in judicial rulings, ${ }^{20}$ a car is not subject to exemption from execution as an object necessary for the obligor's gainful work. Literature claims, however, that this cannot be equated with the prohibition against excluding from enforcement the means of transportation necessary for the obligor to carry out his profession as part of employment. ${ }^{21}$

Things used in churches and other houses of worship for liturgical or Sunday services or to perform other religious practices as well as objects of religious worship should also be considered for exclusion from execution. This precept applies even when these items are valuable or works of art. The fate of these items, and not their value, is what is important.

The second group of exemptions from enforcement includes specific amounts of money. The aim of these exemptions is to leave the obligor with 760 złoty. The exclusion also includes scholarships, money received to cover the cost of business expenses (including travel), and money obtained from compulsory insurance, excluding life insurance.

The third group of exemptions from enforcement includes liabilities and property rights. Savings deposited with banks under the terms and in the amounts specified in the provisions of the Banking Law Act issued on August 29, $1997^{22}$ are not subject to enforcement. According to Article 54, paragraph 1 of this Act, funds reserved in savings accounts, including savings and checking accounts and a time deposit savings account for one person, regardless of the number of contracts established, are free from being pursued based on a juridical or administrative enforcement title in each calendar month in which the seizure is necessary, and up to $75 \%$ of the minimum remuneration for work determined on the basis of the Act of October 10, 2002 regarding the minimum remuneration for the work ${ }^{23}$ of a full-time employee. According to Article 54, paragraph 2 of the aforementioned Act, cash funds accumulated in a savings account, savings and checking accounts, and a term savings deposit account that are established for

$19 \quad$ Ibid, pg. 77.

20 Supreme Administrative Court Decree of March 7, 1997, I SA/Gd 1180/96 LEX 29070; Supreme Administrative Court Decree of May 19, 2000, I SA/Gd 1809/98, LEX nr 44380.

See D.R. Kijowski, in Ustawa o postępowaniu..., pg. 245. 
several physical persons are free from being taken up to the amount specified in paragraph 1 , regardless of the number of joint holders on such an account.

According to the provisions of the aforementioned Act of November 5,2009 regarding cooperative savings and credit unions, execution does not apply to the savings of a person who belongs to a credit union. ${ }^{24}$ According to Article 28 of this Act, the compound savings of a member of a fund deposited at a teller, regardless of the amount of compound savings, are recorded on an individual's account and are free from seizure based on administrative and judicial enforcement in each calendar month, up to $75 \%$ of the minimum remuneration for work determined for a full-time employee based on the Minimum Wage Act.

Excluding remuneration for employment is also important. According to Article 87 of the Labor Code (hereafter abbreviated as 1.c.), ${ }^{25}$ after funds have been deducted as a contribution to social security and advanced payments for personal income taxes, remuneration for work may be withheld, inter alia, from the sums withheld under the enforcement titles. In accordance with Article $87 \S 2$ of the l.c., withholdings from remuneration for receivables specified by the administrative enforcement title shall be made after the executive sums withheld by virtue of the enforcement titles are deducted for maintenance, and before the amounts resulting from cash advances granted to the employee and from financial penalties specified in Article 108 of the l.c. are deducted. It follows from Article $87 \S 4$ of the l.c. that withholdings from remuneration for claims enforced on the basis of other enforceable titles, rather than those pertaining to the satisfaction of maintenance, cannot in total exceed half of the remuneration and three fifths of the remuneration, including the deductions intended to meet such benefits.

Pursuant to Article $9 \S 1$ of the l.a.e.p., provisions that limit the execution of remuneration for work respectively apply to unemployment benefits, activation allowances, scholarships, and training allowanced paid based on the provisions for employment promotion and labor market institutions. These regularizations are also applicable to the dues of members of agricultural production cooperatives and their family members for their work in the cooperative and for all recurring services that they provide to ensure their subsistence. Enforcement limitations, however, do not apply to the claims of members of agricultural production cooperatives due to their share in the cooperative's

$24 \quad$ Dz.U. z 2017 r. poz. 2065 ze zm.

25 The Labor Code Act of June 27, 1974, Dz.U. z 2018 r. poz. 917. 
income that they have accrued from the contributions made to the cooperative.

Exemptions also apply to pensions and annuities. With regard to enforcing cash benefits provided for in provisions for retirement, Article 10 of the l.a.e.p. refers to separate provisions. According to Article 140 of the Act enforced on December 17, 1998 regarding retirement and disability pensions from the Social Security Fund, ${ }^{26}$ cash benefits specified therein are subject to a deduction of up to $60 \%, 50 \%$, or $25 \%$, depending on the type of enforced dues. The aforementioned Act also indicates the amounts that are exempt from deductions, the extent of which is related to types of withholdings to be deducted. The Act's provisions that specify the limits of administrative enforcement apply accordingly to retirement and pensions receive from abroad after they are converted by the borrower of the receivables into Polish złoty according to the rate at which the bank pays the seized amounts to the enforcement authority. Moreover, pursuant to Article $10 \S 2$ of the l.a.e.p., provisions from the enforcement of benefits provided for in regulations on retirement pensions for employees and their families are applicable to the enforcement of pensions due to a work accident or occupational disease as well as pensions awarded by the court or established by a contract for those who have lost their ability to work, or because the breadwinner of a family has died, or disability insurance has been voluntarily paid out and the enforcement of cash benefits due to social insurance in the event of illness and maternity. Furthermore, pursuant of Article $10 \S 4$ of the l.a.e.p., it follows that, among the social security benefits, maintenance advances; payments; family benefits; and accessories for family, caretaking, postnatal needs, and orphans were excluded from administrative execution.

The majority of exemptions from enforcement apply only to actual persons and not to obligors who are legal entities or organizational units without legal personality. The literature suggests that the provisions contained in Article 8 and 8a of the l.a.e.p. can be modified to take into account "real protection of obligors and their assets." ${ }^{27}$ However, in principle, the purpose of the exemptions foreseen by the l.a.e.p. is to protect the obligor and the members of his family from being deprived

\footnotetext{
$26 \quad$ Dz.U. z 2017 r. poz. 1383 ze zm.

$27 \quad$ P. Możyłowski, Zasada poszanowania minimum egzystencji prawna gwarancja ochrony zobowiązanego $w$ egzekucji administracyjnej, in Ochrona praw jednostki $w$ administracyjnym postępowaniu egzekucyjnym, ed. T. Jędrzejewski, M. Masternak, P. Rączka, Torun 2018, pg. 144.
} 
of the assets that would ensure their minimum subsistence level but not protect their economic interests.

The enforcement authority is obliged ex officio to determine whether a given article or property right is enforceable. If the authority finds that a particular asset is excluded, then he cannot include it in the enforcement. The Act does not always define the scope of exemptions precisely, which means that the enforcement authority must assess whether a particular object is subject to enforcement or is exempt from it on the basis of all of the other circumstances of a particular case.

Article 13 of the l.a.e.p. makes it possible to exempt specific assets from enforcement. Exemption from enforcement means that all or part of the obligor's assets cannot be taken or withdrawn by enforcement. Such exemption applies to the assets that are not excluded from enforcement under the law; this may take place when the obligor submits an application in this case, and the release is justified by the obligor's important interest. If the aforementioned conditions are met, then the enforcement authority "may" (but does not have to) release the asset from enforcement. This means that adjudication in these cases is based on administrative acknowledgment. ${ }^{28}$ The order for the assets' release from enforcement favors the obliged complainant.

In conclusion, the development of civilization and social changes that pertain to the standard of living of contemporary societies influence the way that members of societies perceive the subsistence minimum. The legal regulation resultant of Article 8 of the l.a.e.p. gives the obligor a sense of security that his basic material needs as well as his ability to work for pay, which provides a livelihood for him and his family, will be met. Very importantly, it also protects the obligor's assets from being seized, which consequently ensures that the obligor and his family's educational and spiritual needs are met by treating them as those things that are necessary for their existence. Moreover, social honors and merits that the obligor has received (orders, medals, decorations, etc.) are not subject to execution. On the other hand, some actions that the authorities carry out to protect the state are no longer socially acceptable and considered a crime against the state's human dignity. As the doctrine notes, the Constitution of the Republic of Poland upholds the obligation to protect, and ordinary laws are meant to express parliament's observance of the constitution. Moreover, tribunals and courts appointed to do so must assess whether

28 Decree of the Provincial Administrative Court of Gliwice issued on November 5, 2009, I SA/Gl 689/09, LEX nr 566367. 
respect for human dignity is being carried out. ${ }^{29}$ The essential issue, however, that needs to be studied separately is whether non-standard communication activities that are meant to improve the effectiveness of enforcement by admonishing the obligor and urging him to voluntarily follow his civil legal obligations should be introduced into administrative enforcement proceedings.

\section{POSZANOWANIE MINIMUM EGZYSTENCJI JEDNOSTKI W ADMINISTRACYJNYM POSTĘPOWANIU EGZEKUCYJNYM}

Zachodzące we współczesnym świecie przemiany mają wielowymiarowy charakter. W sensie najogólniejszym dotyczą szeroko pojętej kultury i cywilizacji oraz religii. Dostrzegalny jest ich związek z techniką i technologią, co przekłada się na sposób organizacji społeczeństw i sprawowania władzy (politykę) oraz na rodzaj i charakter więzi społecznych, a także kształt gospodarki. Wyraźnie zauważalny jest ich wpływ na samego człowieka, jego sytuację egzystencjalną, stosunek do samego siebie i do otoczenia. Zachodzące zmiany mają też określony wpływ na administracyjne postępowanie egzekucyjne. Jest ono nacechowane elementem przymusu służącego wyegzekwowaniu realizacji obowiązku, którego zobowiązany dobrowolnie nie wykonuje. Z uwagi przede wszystkim na istotną dolegliwość środków przymusu, które mogą być stosowane wobec zobowiązanego w ramach tego postępowania, powinno być ono prowadzone z zachowaniem odpowiedniej dbałości o dobro jednostki. Przedmiotem niniejszego opracowania jest analiza treści zasady poszanowania minimum egzystencji zobowiązanego oraz jej roli jako jednego z instrumentów przeciwdziałających nadmiernej ingerencji organów administracji publicznej w sferę praw i wolności jednostki.

Słowa kluczowe: przymus, administracyjne postępowanie egzekucyjne, minimum egzystencji.

\section{Bibliography:}

1. Act of June 17, 1966 regarding administrative enforcement proceedings, Dz. U. z 2017 r. poz. 1201 ze zm.

2. Act of June 14, 1960, Code for Adminstraive Proceedings, Dz. U. z 2017 r. poz. $1257 \mathrm{ze} \mathrm{zm}$.

3. Act of June 26, 1974, Labor Code, Dz.U. z 2018 r. poz. 917.

4. Act of August 29, 1997, Bank Law, Dz.U. z 2017 r. poz. 1876 ze zm. 
5. Act of December 17, 1998, On Retirement and Pensions from the Social Security Fund, Dz.U. z 2017 r. poz. 1383 ze zm.

6. Act of October 10, 2002, On the Minimum Remuneration for Work, Dz.U. z 2017 r. poz. 847 ze zm.

7. Act of November 5, 2009, On Cooperative Savings and Credit Unions, Dz.U. z 2017 r. poz. 2065 ze zm.

8. Hauser R., Leoński Z., Egzekucja administracyjna. Komentarz do ustawy o postepowaniu egzekucyjnym $w$ administracji, $3^{\text {rd }}$ Edition, Warsaw 1995.

9. Hauser R., Ochrona obywatela $w$ postępowaniu egzekucyjnym $w$ administracji, Poznan 1988.

10. Hauser R., Skoczylas A., Ed., Postępowanie egzekucyjne w administracji. Komentarz, Warsaw 2014.

11. Jędrzejewski T., Masternak M., Rączka P., Administracyjne postępowanie egzekucyjne, Torun 2013.

12. Kijowski D.R., Ed., Ustawa o postępowaniu egzekucyjnym w administracji. Komentarz, $2^{\text {nd }}$ Edition, Warsaw 2015.

13. Możyłowski P., Zasada poszanowania minimum egzystencji prawna gwarancja ochrony zobowiązanego w egzekucji administracyjnej, in T. Jędrzejewski, M. Masternak, P. Rączka ed., Ochrona praw jednostki $w$ administracyjnym postępowaniu egzekucyjnym, Torun 2018.

14. Ofiarska M., Znaczenie zasad ogólnych administracyjnego postepowania egzekucyjnego w orzecznictwie sadów administracyjnych, Annales Universitatis Mariae Curie-Skłodowska Lublin - Polonia, Sectio H Oeconomia 2016, no. 1.

15. Provincial Administrative Court of Gliwice Decree, November 5, 2009, I SA/Gl 689/09, LEX nr 566367.

16. Provincial Administrative Court of Gorzów Wielkopolski, October 30, 2008, I SA/Go 678/08, LEX nr 576720.

17. Przybysz P., Postepowanie egzekucyjne $w$ administracji. Komentarz, Warsaw 2008.

18. Radwanowicz-Wanczewska J., Administracyjne postępowanie egzekucyjne a aksjologia demokratycznego państwa prawnego, in J. Zimmermann, ed., Aksjologia prawa administracyjnego, Vol. 1, Wolters Kluwer, Warsaw 2017.

19. Radwanowicz-Wanczewska J., Poczatki przymusu administracyjnego $w$ prawie rzymskim i praktyce rzymskiej administracji, "Administracja. Teoria - Dydaktyka - Praktyka" 2015, No. 4 (41).

20. Służewski J., Ed., Postępowanie administracyjne, Warsaw 1975.

21. Smoktunowicz E [et al.], ed., Wielka encyklopedia prawa, Warsaw Białystok 2000.

22. Supreme Administrative Court Decree, December 18, 1996, SA/Łd 2983/95, LEX nr 28977.

23. Supreme Administrative Court Decree, March 7, 1997, I SA/Gd 1180/96, LEX 29070.

24. Supreme Administrative Court Decree, May 9, 2000, I SA/Gd 1809/98, LEX nr 44380. 